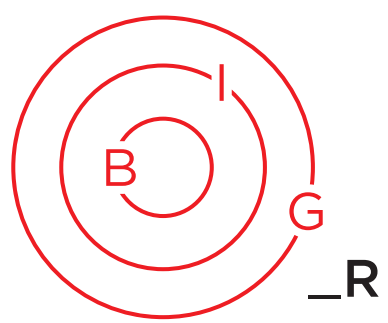

ESSAY

\title{
The Dutch-German Border: Open in Times of Coronavirus Lockdowns
}

\author{
Martin van der Velde \\ Doede Sijtsma ii \\ Maarten Goossens ii \\ Bas Maartense iv
}

This essay portrays policies, practices and perceptions at the DutchGerman border during the first year of the COVID-19 pandemic. Before that this border was considered one of the most open borders in the world. The first part of the essay deals with the waves of policies and other initiatives aimed at limiting cross-border traffic that have been introduced since March 2020 trying to curb the pandemic. The second part illustrates to what extent these policies might have had an effect on citizens' cross-border practices and perception of the border.

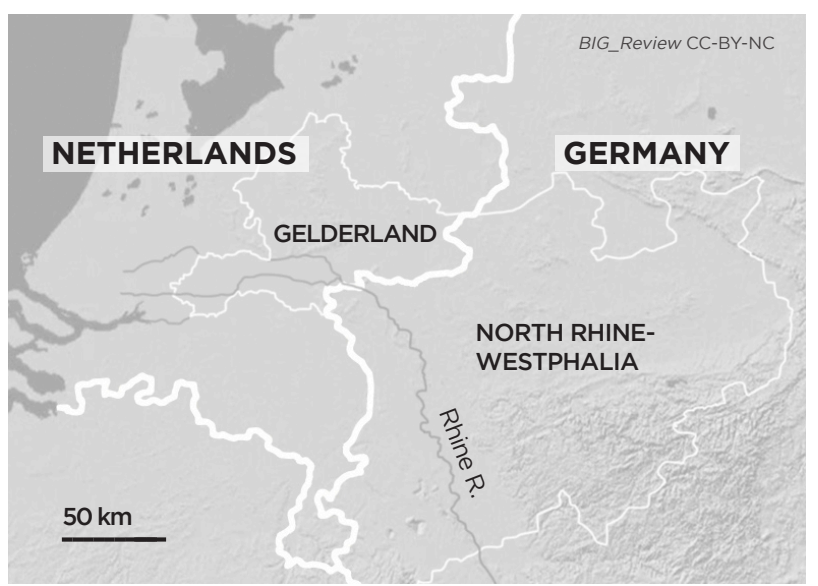

\section{Introduction}

Many consider the Dutch-German border as one of the most open borders in the world. At first sight this certainly seems to be true. But already before the current COVID-19 crisis cross-border travelling was regularly monitored. Under normal circumstances the Schengentreaty does not allow for controls and checks right at the border, but the Dutch had so-called 'flying brigades' that 'profiled' traffic a few hundred meters away from the border. These checkpoints were officially labelled as 'Mobile Security Surveillance' (Mobiel Toezicht Veiligheid) and not specifically as border control. They were sometimes employed for instance during the refugee crisis that peaked around 2015.

i Martin van der Velde, PhD, Associate Professor, Nijmegen Centre for Border Research, Department of Geography, Planning and Environment, Nijmegen School of Management, Radboud University Nijmegen. Email: M.vanderVelde@fm.ru.nl

ii Doede Sijtsma, Drs, Germany Representative, Provinces of Gelderland and South-Holland. Email: D.Sijtsma@gelderland.nl Twitter@Doede_in_DE

iii Maarten Goossens, MSc, Project Officer, Euroregion Rhine-Waal (Interreg Germany-Netherlands, Joint Secretariat) Email: Goossens@euregio.org

iv Bas Maartense, (BA-Sc) MA-Student Human Geography, Nijmegen School of Management, Radboud University Nijmegen. Email: BasMaartense@gmail.com 
Under the Schengen regulation, countries do have the rights to setup border control points for a limited amount of time in order to regulate the cross-border flow of people in case of a "foreseeable threat to public policy or internal security" such as during high risks events, possible societal disruption, terrorist threats, diseases etc. These temporary checks serve the purpose of basically keeping out certain groups of people and transports. The border controls during the COVID-19 pandemic (which will probably exceed the time limits set in the Schengenagreement for temporary border controls) serve a different goal. This time it is (or was) not about denying people access where the 'normal' is free entry, but more pinpointing those that are allowed in, where the reference is no border-crossing activities. Countries are constantly looking for a balance between sealing their borders hoping to keep the coronavirus out and providing access to certain activities.

In this context this essay will deal with the developments and situations at the Dutch-German border with a focus on the border between the province of Gelderland (The Netherlands) and the federal state of North RhineWestphalia (Germany). After a general introduction, this essay will present a timeline of border interventions. The next sections will deal with two possible consequences of these interventions and the pandemic in the border region. The first one is the development of cross-border traffic. The second one concerns the possible consequences of the pandemic on the perception of the border, border policy and the neighbouring country.

\section{Coronavirus and policies at the Dutch-German border}

Throughout the world, the European Union not excluded, borders were closed in an effort to protect societies from being contaminated from abroad. The impact of such a measure on society is particularly large if the norm is that borders are open with no significant border control. This is the case in the parts of Europe covered by the Schengen area. Cross-border commuting, international supply chains, shopping on the other side of the border, visiting family and friends or taking the shorter route to your destination through the other country has been considered normal for Europe's internal borders for about thirty years. For many younger Europeans, a first trip outside the European Union is also the first experience with classic (normal) border control.

Whereas elsewhere in Germany the borders with neighbouring countries were soon (partly) closed, the border between Germany and the Netherlands remained open during the COVID-19 crisis. This was not uncontroversial. There were German federal states, in line with the view of the Ministry for the Interior, that opted for equal treatment of all German borders. The interests to keep the Dutch-German border open were very high. Not only the approximately 50,000 commuters in this area are involved, also a large proportion of the goods used in Europe, but produced outside Europe, are transported across this border from the ports of the Netherlands and Belgium to their destination. At various other borders (e.g. the Polish-German border) there were long delays for freight and passenger traffic caused by closures or restrictions at the border. Delays in goods transport between the Netherlands and Germany could quickly lead to production problems in German industry or supply insecurity for agricultural products in supermarkets (the Netherlands is the second largest exporter of agricultural products in the world after the USA; Germany is a major destination). Shortages-much more than just the hoarding of toilet paper-could lead to unrest.

Both in the Netherlands and Germany, the policy was and is aimed at curbing the spread of the COVID-19 virus by limiting the number of contact moments between people. For this reason, both the German and the Dutch side of the border have been asked to refrain from unnecessary travel across the border. Without this being precisely defined, travel to work or transport of goods were generally considered necessary. Examples of non-necessary travel were daily groceries, visits to friends and family or refuelling on the other side of the border.

This call to voluntarily refrain from unnecessary travel across the border was also supported by local and regional administrators especially in the northern part of the border region. One of the actions was a bilingual campaign on social media with the message 'Good neighbours keep their distance' and do not visit each other now.

What was also considered necessary in such a situation is to coordinate German and Dutch (and Belgian) policies. In March 2020, primarily structured along the lines of the regular (intensive) cross-border cooperation between the Netherlands and North Rhine-Westphalia, a joint task force (Cross-border Taskforce Corona) was set up to exchange information between Germany, the Netherlands and Belgium. Policy coordination was also

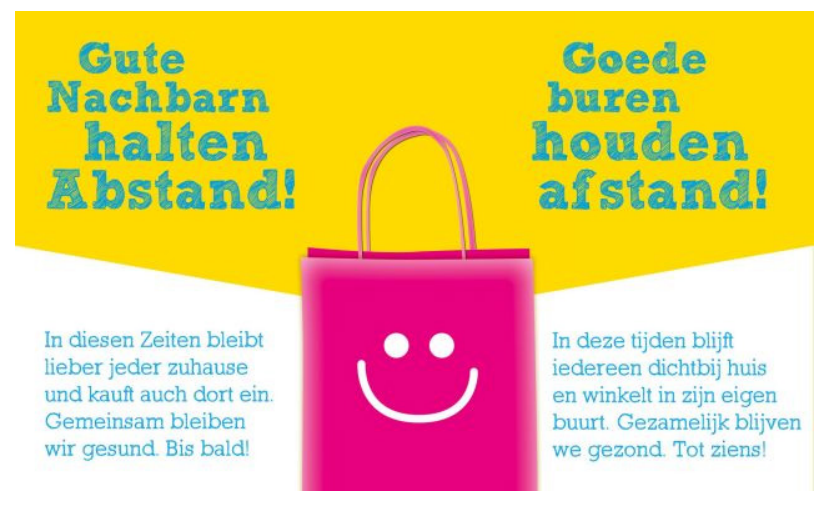

Figure 1: Good neighbours keep their distance! The text reads: "In these times, everyone stays close to home and shops in their own neighbourhood. Together we stay healthy. See you soon!" Source: Grenspost Düsseldorf (https://www. grenspostdusseldorf.nl/goede-buren-houden-afstand/) 
intended to prevent the creation of undesirable push and pull factors due to differences in the measures taken. For instance, anyone who could no longer go to their own 'domestic' hairdresser but could still get a haircut nearby but across the border, may be tempted to cross.

A special case in need of coordination concerned the outbreaks of the virus in slaughterhouses in the Dutch part of the border region. The problem was not so much the outbreak itself, but more the fact that these companies make extensive use of foreign workers mostly from Central European countries, hired through temporary employment agencies. They live often in group-accommodations and are brought back and forth to the workplaces in vans. The corona measures, especially the 1.5-meter distance, were often not observed in the workplace, the group accommodation, or in the commute. The cross-border aspect here is that some of these workers were accommodated on the German side of the border. As organisations in the two countries are involved (the Dutch agencies concentrating on the situation in the slaughterhouse and the German governmental agencies trying to control the pandemic where the workers lived), good communication and coordination between the health services on the Dutch and German sides of the border is necessary. Here, too, it proved possible to set up communication and coordination relatively quickly by using the existing cross-border contacts between authorities.

\section{Timeline of corona measures related to the Gelderland-North Rhine-Westphalian border ${ }^{1}$}

March 16, 2020: The borders of Germany with Austria, Switzerland, Denmark, France, and Luxembourg are closed for non-professional traffic. Border between the Netherlands and Germany (and Belgium) remains open.

Mid-March: Kreis Borken (a district in the northern part of this border-region) sends a letter to the German government indicating that it is important that the rules on both sides of the border should be made more equal to keep the border open in a safe way.

March 18: The Netherlands introduces Code Orange for travelling to Germany. This means that only necessary trips are allowed, holiday travel/day tourism is discouraged. However, this is not really enforced; it remains a strongadvice. Cross-border professional traffic is subject to an obligation to carry a 'Pendlerbescheinigung', a declaration stating that the person is working across the border. This, too, is rarely or not enforced.

March 21: Cross-border Corona Task Force is established. This is to support the cooperation between the Netherlands, Germany, and Belgium to better coordinate the handling of the crisis.

April 2: The Dutch government urges Germans (and Belgians) to stay away from the Netherlands over the Easter weekend.
April 10 - Mid May: Quarantine measures are installed in Germany, requiring those travelling into Germany from another country to spend two weeks in home quarantine. Workers, goods and international transit are exempt.

June 15: The German borders with Austria, Switzerland, Denmark, France and Luxembourg are reopened for all traffic. Non-essential traffic between Germany and the Netherlands is again without any border control (which in practice was never really enforced).

August 8: Corona test is required for everyone travelling (back) to Germany. Local border traffic remains possible, without test. Cross-border commuters and people who want to visit family must report themselves once to the local health department.

September: A second wave of corona infections emerges in the Netherlands.

October: Germany experiences also the start of a second wave.

October 13: The Netherlands in partial lockdown with again the advice to travel as little as possible.

October 15: The whole of the Netherlands is classified as a risk area for Germany. Non-essential traffic for German citizens towards the Netherlands is discouraged and an official travel warning applies for Dutch citizens. All Dutch citizens must undergo quarantine measures and test before entering the country. Local border traffic to North Rhein Westphalia remains possible.

October 28: The Netherlands designate ten larger cities in Germany as Code Orange (only necessary travel), including the North Rhine Westphalian cities of Köln, Düsseldorf, and Essen.

November 3: The Netherlands implements Code Orange for the whole of Germany. Only essential travelling is allowed, and a corona test is required upon return.

November 20: The government of North Rhine Westphalia decided that the quarantine measures are suspended for people who travel to or from the Netherlands. It remains required to report oneself and to be able to show a negative PCR-test. This is not the case for visits that last less than 24 hours. Local border traffic is thus possible.

January 23, 2021: All travellers from Germany must quarantine themselves when entering the Netherlands. However, there still are exceptions such as travel for work or family reasons.

March 1: People who travel into Germany receive a 'Corona-SMS' from providers on behalf of the German government with the text to adhere to the test and quarantine instructions.

April 6: Germany declares the Netherlands as a high-risk country. Dutch citizens must be able to show an official negative corona test result not older than 48 hours when crossing the border into Germany. Until then it was only required to do this in the first 48 hours of a stay in Germany. Small border traffic is now also affected. 
Borders in Globalization Review | Volume 2 | Issue 2 | Spring/Summer 2021

van der Velde, Sijtsma, Goossens, and Maartense, "The German-Dutch Border: Open in Times of Coronavirus..."

\section{Cross-border mobility}

With regard to cross-border mobility, the corona measures were especially meant to curb non-essential trips. In this respect many Germans travel to the Netherlands, for example, on the weekends to shop. Visiting the Dutch weekly markets is especially popular. Closing these markets (e.g. in Winterswijk) has therefore contributed to reducing cross-border traffic. Many Dutch people travel in the opposite direction, to shop for goods that are only available or considerably cheaper in the neighbouring country. In Germany many more shops were forced to close, compared to the Netherlands, and this also had an impact on need to cross the border.

The province of Gelderland monitors the traffic on the provincial roads and has also made an overview of the differences between the time just before the corona crisis and the weeks after. For the provincial roads this gives the following picture (Figure 2):

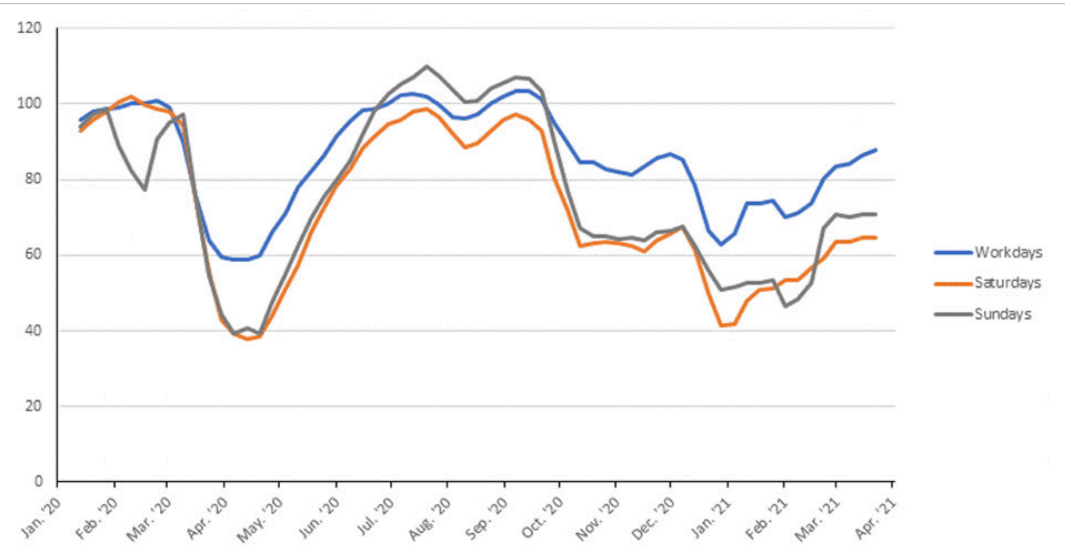

Figure 2. Index of total cross-border traffic at 5 border crossings (March 2, 2020 = 100; three-week moving average). Source: Province of Gelderland.
In March 2020 traffic initially drops sharply (especially at weekends when there is less commuting), but the situation returns to 'normal' after mid-June. Another sharp decline occurred at the start of the second partial lockdown in October to about 60 to 80 percent of the pre-COVID-19 levels. It dropped even further when a stricter lockdown was announced mid-December. Early 2021 cross-border traffic rose gradually again.

Differences have been observed between five provincial border crossing roads where the province counts the number of cars (Figures 3 and 4).

It is striking that the decline in non-essential traffic in Winterswijk in the north-eastern part of this border region seemed to be much greater than in other parts. Among other reasons this may have been because municipalities in this part of the region communicated more actively about the desirability of not going abroad.

\section{Changing perception of the border and the "other"?}

At the time of the corona crisis, the Euregion Rhine-Waal (Joint INTERREG Secretariat), carried out a "flash" study on the influence of the corona crisis on the perception of borders (especially as a barrier) and the "other" (as an expression of identity) amongst a sample of 84 Dutch and 31 German citizens in the border region. The survey

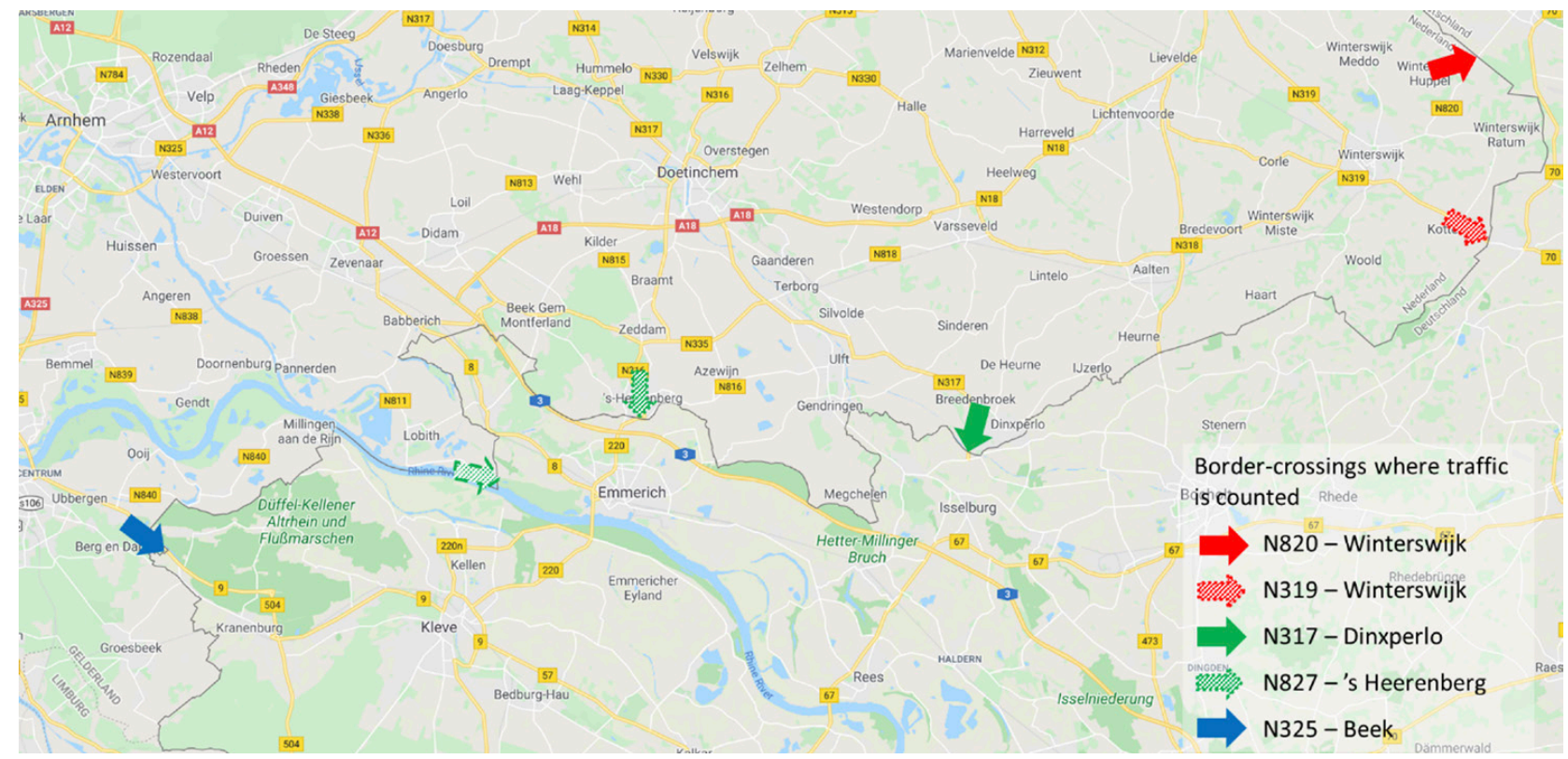

Figure 3. Cross-border traffic data collection points. Adapted from Google Maps. 
Borders in Globalization Review | Volume 2 | Issue 2 | Spring/Summer 2021 van der Velde, Sijtsma, Goossens, and Maartense, "The German-Dutch Border: Open in Times of Coronavirus..."

was conducted in April and May 2020, when the "lockdown" was at its height. Respondents did not often think that the Dutch-German border should have been closed (approximately 10 percent thought so). Not surprisingly many respondents indicated that they perceived the border more as a barrier in April and May 2020. In the case of economic cross-border interaction 45 percent indicated a larger perceived barrier effect. For socio-cultural interaction this was a little higher with 51 percent. It seems feasible to state that the corona crisis has increased the perception of the border as a barrier.

Respondents who took the coronavirus more seriously generally felt a stronger national identity compared to respondents who thought of the coronavirus as less worrying. This could hint at the fact that the corona crisis has made the feelings of national identity stronger. People seem to have generally developed a stronger national identity because of the corona crisis. When asked directly, by presenting a proposition on the relation between the perception of coronavirus and identity-feelings, however, this did not surface. Only 13 percent of the respondents stated explicitly that they felt more Dutch or German because of the corona crisis and only 3 percent indicated that they preferred to deal only with fellow countrymen during the corona crisis. This could mean that the effect of the corona crisis on national identity plays out in the subconscious, i.e., that people did not consciously develop a stronger national identity. Possible implications of this observation are difficult to draw right now, as it must first be clear whether this development will remain once the crisis is over.

\section{Conclusion}

This essay has offered some insights in the developments of cross-border mobility and feelings in the DutchGerman border region in times of crisis. It comes as no surprise that in the early stages the crisis had a big impact on physical mobility. But mobility seems also to be quite 'resilient', witnessing the return to the levels of mobility before the crisis. It also seems that the relative lenient policy measures have not really affected the spread of the virus either in a positive or negative way. Policy-measures are confined by the border, but the virus is not. Of course, restricting border traffic reduces the number of contacts especially in the border region. This might help to curb the spread of the virus regionally, but it remains a question to what extent this also has a major effect on the development of the virus within the country. We do not know what would have happened had more (or less) drastic measures been taken. But it is safe to say that coordination and cooperation is especially important. Between the Netherlands and Germany, the base for cooperation, trust in each other, is already in place and the additional steps that had to be taken in the current crisis flowed naturally from it.

\section{Note}

1 Timeline co-compiled by Lars Kleijne, MA-student Human Geography, Radboud University, Nijmegen.

Editors' Note: This essay was prepared for the previous special issue but was not included at the time due to editorial issues. The data and timeline have been have been updated.

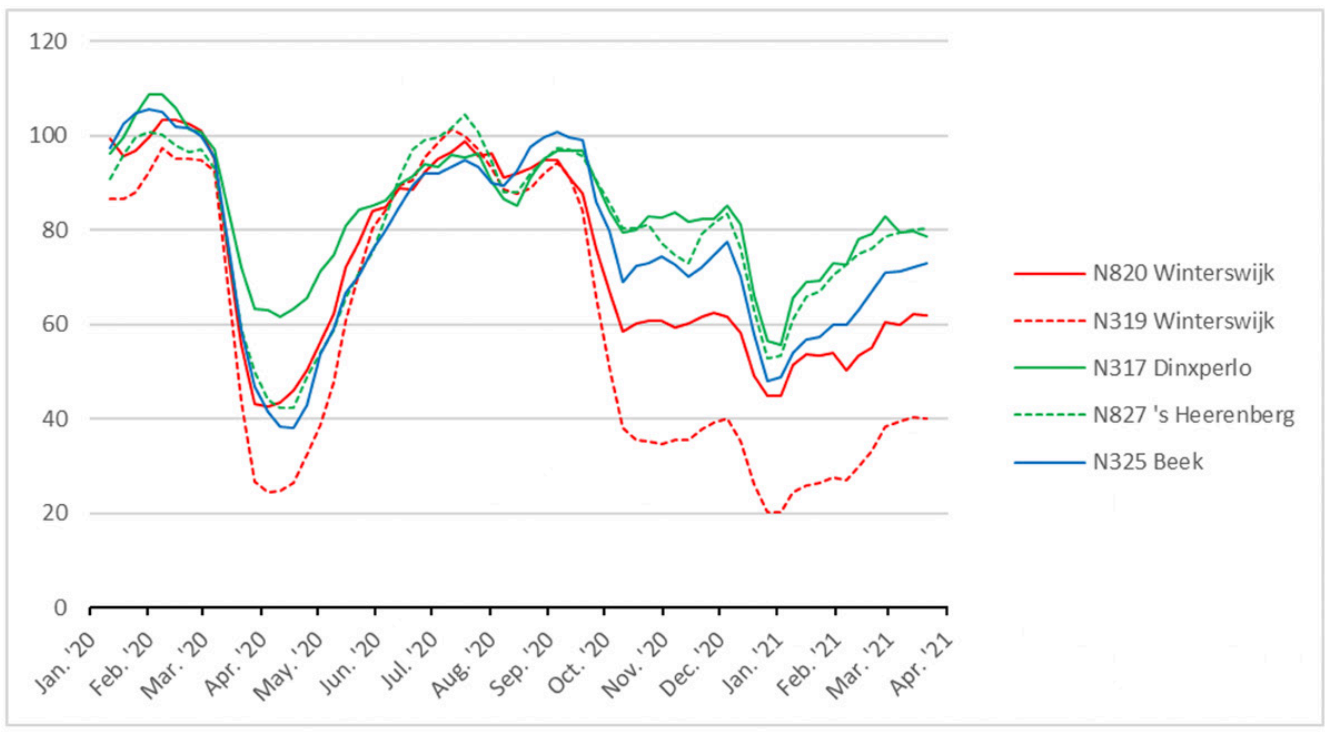

Figure 4: Index of cross-border traffic on Saturdays (March 2, $2020=100$; three-week moving average). Source: Province of Gelderland. 